\title{
SECRETORY CANALS OF RHUS DIVERSILOBA
}

\author{
JAMES B. MCNAIR
}

In Rhus diversiloba $\mathrm{T}$. and $\mathrm{G}$. the resin passages are situated in the roots, stems, leaves, and fruit in the phloem of the primary vascular bundles. In addition, there are others in the secondary bast of the stem and root.

The root contains a single wide resin canal in each of the phloem portions of the primary bast. In the secondary bast, resin canals in concentric circles with smaller lumina are successively added. After the secondary phloem is formed in the root, the xylem and phloem are formed exactly as in the stem.

In the stem the phloem portion of the primary bundles is separated from the parenchymatous outer cortex by a strong bundle of sclerenchymatous (bast) fibers of crescent-shaped transverse section. These fibrous bundles are almost in contact with one another at their margins, and thus constitute a ring around the outer cortex. Outside of this sclerenchymatic ring no resin passages are found, but large ones are located immediately within it, one in the phloem of each vascular bundle. In the secondary cortex, which, is formed later internally, new canals are formed successively in the strands of the bast. The cortical passages of the secondary bast are connected in the internodes by more or less numerous tangential anastomoses, and thus combine to form a more or less complete cylindrical network in the bark concentric with the stem cylinder. The cortical passages in the nodes anastomose with one another. The leaf passages extend up the internode to the plexus of anastomoses.

The vascular bundles which pass into the petiole are arranged in curves to follow the outline of the petiole in its transverse section. These branch when they reach the leaflets. The resin passages are arranged in the petiole as in the primary vascular bundles. The canals may be absent in the weaker bundles, however.

In the midrib of the leaflets the fibrovascular system is divided into two parts. One, the superior, the ventral, is formed of 3 
reunited bundles placed under the endophloem; the other, the dorsal, has $5^{-7}$ bundles arranged in an arc, and has also $5^{-7}$ resin passages in the phloem parts.

All lateral ribs contain at least one passage on their dorsal sides, which is in the phloem as usual. Some of the resin canals seem to end blindly in the spongy parenchyma and palisade parenchyma, while others apparently anastomose in a reticulate manner like the vascular bundles which they accompany.

TRECUL (7) noticed in Rhus Toxicodendron L., to which $R$. diversiloba is very closely allied, the obstruction of the resin canals at the base of the petiole just before the fall of the leaves. This obstruction is effected by an increase in the parietal cells of the canals, and thus constitutes an instance of tylosis, similar perhaps to the obliteration of the old canals in the bark. The enlarged cells divide and the new ones produce more of the same kind. Soon the ducts are seen on the outside of the parenchyma at the place of insertion of the leaves. At a small distance away in the leaflet the passages have a normal appearance and are filled with sap.

Resin passages in $R$. diversiloba are found also in the mesocarp of the fruit and in the hypocotyl and cotyledons of the embryo, likewise in the phloem. It is interesting to notice how early in the life of the plant these organs of secretion are found, and yet they are confined from first to last in the phloem group.

According to SIEcK (5), the resin canals of the Anacardiaceae are of schizolysigenous origin. ${ }^{\mathrm{x}}$ The first development of the intercellular cavities can readily be observed in $R$. diversiloba, which has good clear channels. In the beginning the evolution of the resin tube in this plant is clearly schizogenous. It forms itself from a little group of cells individually much narrower than the other parenchyma cells. A short slit soon appears toward the center of the group. When this slit enlarges itself, a little of the resinous sap appears. The opening, first irregular in outline, enlarges to a channel of considerable size with a regular circular outline and is bordered by narrow cells. This is by far the form most commonly

${ }^{I}$ It should be stated that SIECK worked with Anacardium occidentale, which is not very closely related to Rhus diversiloba, a fact which may explain the apparent difference in origin of the secretory canals. 
noticed and is plainly schizogenous. Some of the secreting cells may eventually break down altogether, to leave their secretions in the cavity formed by their disintegration and thus be designated lysigenous in character. Cavities so appearing in my investigations of this plant may have been due to imperfect sections. At any rate, lysigenous cavities are apparently in the minority.

If these observations be compared with previous works on other Anacardiaceae, it will be seen that there are no essential differences in the arrangement of the intercellular secretory reservoirs. Which genera should be poisonous, or why their poisons should vary, either in physiological action or in chemical composition, cannot be deduced from this part of their anatomies.

Plants other than the Anacardiaceae that secrete resin, emulsions of gum-resin, etc., in passages are as follows: Coniferae, Alismaceae, Aroideae, the tubifloral Compositae, Umbelliferae, Araliaceae, Pittosporeae, many species of Mamillaria, Clusiaceae, and Ailantus and Bruceae of the Simarubeae.

The abundance and comparatively large size of the resin ducts, together with their fusing, make an intercommunicating system. When a wound is made, the sap and its poison are quickly pressed out, either by the tension of the elastic walls of its own cells or by a combination of both. In the spring the sap is very watery, while the autumn product is much thicker, granulous, and slower in exudation. The sap, which is properly an emulsion, is, when first expressed, white or light gray in color, and as it quickly coagulates and browns in the air, it forms an efficient covering for the wound. The sap is darkened in the air mainly by oxidation, as has been shown in a former paper (3): first, when deprived of oxygen the sap darkens but very slowly; secondly, when in the presence of oxygen the sap darkens rapidly; and finally, ultimate chemical analyses of the sap before and after darkening show an appreciable difference only in the oxygen content.

Under the microscope the freshly exuded sap is in part a colorless liquid and in part made up of minute globules. Very soon some of these globules become dark brown, while the fewer remaining globules continue to be colorless. While this change has been taking place, oblong rectangular colorless crystals separate out. The first crystals to separate are larger than those which form 
later. This process of crystallization probably has its cause in the evaporation of the menstrum. If these crystals be viewed through a petrographic microscope, they are seen to be birefringent, similar perhaps to those noticed by WIESNER (8) in the sap of $R$. vernicifera. On adding water the light colored globules disappear, but the brown ones remain. The addition of alcohol, on the other hand, causes the solution of the brown globules.

The freshly exuded resinous sap of $R$. diversiloba has been shown to be the only part of the plant capable of producing dermatitis (2). Consequently those portions of the plant that do not contain the resin ducts do not have this kind of toxic effect. The non-toxic portions are the anthers, pollen, xylem, trichomes, epidermis, and cork cells. The poison has also been shown to be non-volatile, although it may be carried by the particles of soot in smoke.

INUI (I) has noticed that the amount of secretion of $R$. vernicifera is influenced by the conditions of light and atmospheric humidity. In potted plants the secretion lessened when carbon assimilation was hindered. Similarly secretion was greater in damp than in dry air. This secretion therefore seems to bear a relation to transpiration and hence to turgor. As the degree of turgor varies indirectly with the amount of transpiration, other things being equal, secretion would be least when transpiration is greatest. Turgor, too, is a necessary accompaniment of growth; flaccid tissues do not grow larger. If those influences which affect $R$. vernicifera have a similar action on $R$. diversiloba, then secretion, and consequently the plant conditions for poisoning, would be greatest during that time of the year when the growth of the plant is most active and the tissues least resistant, in the spring. Obviously enough, when the plant is in full leaf and when growth has diminished, its resistance to injury will be greater and its liability of poisoning less.

In autumn the charming appearance of the luxuriant foliage, when it turns to many shades of scarlet and bronze, speaks a flagrant warning to its victims and is only especially alluring to the unsuspecting. Nevertheless, either the amount or the virulence of the poison in the autumn leaves is less than that of the normal mature leaves (3). Of the autumnal leaves the red are less toxic than the yellow, and when the leaves have finally withered and 
fallen they are non-toxic. During that period of the year when the plant is leafless the risk of its producing poisoning is least.

This theoretical consideration of the liability of Rhus poisoning from a botanical point of view has its counterpart in clinical statistics. The latter lend analogous evidence to the conclusion that spring has the greatest number of cases (see frequency polygons) (9).

The number of cases of dermatitis from $R$. diversiloba is influenced, not only by the condition of the plant, but also by those conditions which tend to make individuals come in contact with it or with substances coated with its poisonous sap. ROBERT LOUIS Stevenson (6) describes a tramp in California woods as follows:

We struggled toughly upward, canted to and fro by the roughness of the trail, and continually switched across the face by sprays of leaf or blossom. The last is no inconvenience at home; but here in California it is a matter of some moment. For in all woods and by every wayside there prospers an abominable shrub or weed, called poison-oak (Rhus diversiloba).

Many low plants seek the shelter of the Rhus diversiloba shrubs, and some of our loveliest flowers, such as Clarkias, Godetias, Collinsias, Brodiaeas, and Larkspurs, seem to realize that immunity from human marauders is to be had within its safe retreat. JoHN MUIR (4) "oftentimes found a curious twining lily (Stropholirion californicum) climbing its branches, showing no fear but rather congenial companionship." The desire to gather spring wild flowers is often greater than the fear of Rhus diversiloba. Circumstances thus combine to bring victim and culprit together at the time when the culprit is capable of doing the most harm. It may truthfully be said in regard to this poisonous plant, as is said of the Scotch thistle, "no man provokes it without fear of punishment."

\section{Summary}

I. The intercellular secretory canals of Rhus diversiloba T. and G. are found in the roots, stem, leaves, and fruit in the phloem of the primary vascular bundles. There are other secretory canals situated in the secondary bast of the stem. They are found also in the phloem of the mesocarp of the fruit and in the hypocotyl and cotyledons of the embryo.

2. Their formation may possibly be schizolysigenous. In the beginning they are clearly schizogenous. 
3. There are no essential differences in the arrangement of the intercellular secretory reservoirs between the poisonous and nonpoisonous Anacardiaceae.

4. From an anatomical standpoint there is no reason why the poisons of the Anacardiaceae should vary either in physiological action or in chemical composition.

5. The fresh sap emulsion is the only part of the plant capable of producing dermatitis.

6. Those portions of the plant that do not contain the resin ducts do not normally have this kind of toxic effect.

7. The non-toxic portions are the anthers, pollen, xylem, epidermis, cork cells, and trichomes.

8. The liability of poisoning from $R$. diversiloba tissues decreases as follows: immature leaves and flower parts (except anthers and pollen), mature leaves, green stems, young roots, woody stems, and woody roots.

9. The liability of poisoning from $R$. diversiloba is greatest in the spring, less in the summer and fall, and least when the plant is leafless.

Pasadena, Cal.

\section{LITERATURE CITED}

I. Inur, T., Gummiharzang d. Lackbaumes, U.S.W. Bot. Centralbl. 3:352-1900.

2. McNair, James B., The transmission of Rhus poison from plant to person (Rhus diversiloba T. and G.). Jour. Infect. Diseases 19:429-432. I9I6.

3. - The oxidase of Rhus diversiloba. Jour. Infect. Diseases 20:485498. 1917 .

4. Murr, John, My first summer in the Sierra. Boston and New York. IgI I (pp. 34, 35).

5. SIECK, W., Die schizolysigenen Secretbehälter. Jahrb. Wiss. Bot. 27:227. pls. 6-9. 1895 .

6. Stevenson, R. L., Napa wine III. - In the valley. The Silverado squatters. 1883.

7. Trecul, M. A., Des Vaisseaux propres dans les terebinthínees. Compt. Rend. $65: 17.1867$.

8. Wiesner, Julius, Die Rohstoffe des Pflanzenreiches I: 299. I900.

9. MCNaIR, James B., Pathology dermatitis venenata from Rhus diversiloba. Jour. Infect. Diseases I9:419-428. I916. 


\section{$2 \mathrm{BHL}$ Biodiversity Heritage Library}

Mcnair, James B . 1918. "Secretory Canals of Rhus Diversiloba." Botanical gazette 65(3), 268-273. https://doi.org/10.1086/332233.

View This Item Online: https://www.biodiversitylibrary.org/item/109339

DOI: https://doi.org/10.1086/332233

Permalink: https://www.biodiversitylibrary.org/partpdf/223991

\section{Holding Institution}

Missouri Botanical Garden, Peter H. Raven Library

\section{Sponsored by}

Missouri Botanical Garden

\section{Copyright \& Reuse}

Copyright Status: Public domain. The BHL considers that this work is no longer under copyright protection.

This document was created from content at the Biodiversity Heritage Library, the world's largest open access digital library for biodiversity literature and archives. Visit BHL at https://www.biodiversitylibrary.org. 